https://helda.helsinki.fi

\title{
Young females at risk while driving with a small child
}

\section{Maasalo, Ida Emilia}

2017-11

Maasalo , I E , Lehtonen , E P \& Summala , K H I 2017 , ' Young females at risk while driving with a small child ' , Accident Analysis and Prevention , vol. 108 , pp. 321-331 . https://doi.org/10.1016/j.aap.2017.09

http://hdl.handle.net/10138/228445

https://doi.org/10.1016/j.aap.2017.09.012

acceptedVersion

Downloaded from Helda, University of Helsinki institutional repository.

This is an electronic reprint of the original article.

This reprint may differ from the original in pagination and typographic detail.

Please cite the original version. 
YOUNG FEMALES AT RISK WHILE DRIVING WITH A SMALL CHILD

Authors:

Ida Maasalo a,

Esko Lehtonen ${ }^{\mathrm{a}, \mathrm{b}}$ and

Heikki Summala ${ }^{\text {a }}$

${ }^{a}$ Traffic Research Unit, Cognitive Science, University of Helsinki, Finland

${ }^{\mathrm{b}}$ Transportation Research Group, School of Psychology, University of Waikato, New Zealand

Emails:

ida.maasalo@helsinki.fi

esko.lehtonen@helsinki.fi

heikki.summala@helsinki.fi

Corresponding author information:

Ida Maasalo, Traffic Research Unit, PO Box 9, FIN-00014 University of Helsinki, +358 0294129420

NOTICE: This is the author's version of a work that was accepted for publication in Accident Analysis \& Prevention. Changes resulting from the publishing process, such as editing, corrections and structural formatting may not be reflected in this document. A definitive version was subsequently published in: https://doi.org/10.1016/j.aap.2017.09.012 


\section{HIGHLIGHTS}

- Analysis of characteristics and risk of crashes among female drivers with an infant passenger.

- Crashes involving infants typically occurred in ordinary driving conditions.

- Drivers with an infant passenger were more often fatigued or inattentive than drivers with no passengers.

- Young females are at an elevated risk of fatal crashes when driving with an infant passenger.

- An adult passenger in addition to an infant passenger lowered drivers' risks regardless of the driver's age. 


\begin{abstract}
Introduction: Previous research suggests that young mothers with little driving experience are at risk when driving with a small child passenger. In this study we examined the prevalence, characteristics and risk of fatal motor vehicle crashes involving an infant passenger under the age of one among female drivers of different ages.
\end{abstract}

Methods: We used crash data from the US Fatality Analysis Reporting System for 1994-2013. The prevalence of fatal crashes involving infants was examined by age of female drivers and compared to the number of births among mothers of a similar age. The essential characteristics of the crashes were described, and the odds of being at fault were determined for young (16-24-year-olds) and older female drivers (25-39-year-olds) with an infant passenger or with no passengers.

Results: The prevalence of fatal crashes involving infant passengers was higher among young female drivers in relation to the number of births among mothers of a similar age than among older females. Young female drivers with an infant passenger were more often at fault than older drivers $(\mathrm{aOR}=1.83$, $95 \%, \mathrm{CI}=1.52,2.20)$. Their vehicles were older and smaller and they used proper safety seats for infants less often than the older drivers. In addition, young female drivers with an infant passenger but with no adult passenger in the vehicle were more often at fault than young female drivers with no passengers $(\mathrm{aOR}=1.27,95 \% \mathrm{CI}=1.06,1.51)$.

Both young and older female drivers' crashes involving an infant passenger typically occurred in ordinary driving conditions, but these drivers with infant passengers were more often reported as having fallen asleep or inattentive than those with no passengers. The presence of an adult passenger in addition to an infant passenger lowered female drivers' odds of being at fault, regardless of the driver's age.

Conclusions: Young females driving with an infant passenger, probably most often mothers, are at an elevated risk of a fatal crash, especially when they drive alone with an infant. The protective effect of an adult passenger suggests that another adult in the vehicle can assist the driver by taking care of the infant and enabling the driver to focus on driving.

\title{
KEYWORDS
}

Motor-vehicle accidents; Responsibility analysis; Young drivers; Child passenger; Infant passengers; Adult passenger 


\section{INTRODUCTION}

Road traffic crashes are the leading cause of injury-related deaths of children across the world. ${ }^{1}$ In order to reduce the deaths of child passengers, previous research has mainly investigated how children's injuries and deaths can be prevented by restraint systems and safety seats. ${ }^{2,3,4}$ Although it is important to mitigate the consequences of traffic crashes involving children, it is also important to study why these crashes occur in the first place.

According to previous research, parents of small children seem to be motivated to drive responsibly and are unlikely to take risks on the road. ${ }^{5}$ Crashes involving child passengers usually occur during daylight under normal driving circumstances ${ }^{6,7}$ and drivers in crashed involving children less often speed or are under the influence of alcohol. ${ }^{8,9}$ The results of a study based on naturalistic driving data suggested that children being in the rear seats reduces drivers' risk of crashing. ${ }^{10}$

However, child passengers themselves may present a source of distraction, by competing with the driving task for the driver's attention. ${ }^{11,12}$ Our recent analysis of fatal crashes indicated that the risk among female drivers is especially elevated when they drive with small 0-4-year-old children compared to similar drivers with no child passengers. ${ }^{9}$ However, this was not the case among male drivers, suggesting that females are more vulnerable to small child-related distraction. A crying infant in the vehicle might be a significant distracting factor for a mother, as the primary function of crying is to get attention from caregivers. ${ }^{13}$ The mothers of small children may also be exposed to sleep disruption and fatigue ${ }^{14,15}$ and preliminary results suggest that new mothers' sleep problems might be linked to a higher crash risk ${ }^{16,17}$. In addition, over $10 \%$ of mothers suffer from postpartum depression. ${ }^{18}$ Consequently, they may be less careful with their children by for example, using safety seats in vehicles less frequently than non-depressed mothers. ${ }^{19}{ }^{20}$ Depression might also have an impact on drivers' crash risk. ${ }^{21}$

As far as we know, no research exists on the association of the crash risk with a small child passenger and the age of the driver. Earlier studies have shown that infants of young mothers are at a higher risk of motor vehicle-related deaths than infants of older mothers ${ }^{22,23}$, but the reason for this is not clear, and it is not known whether this difference still exists today. If it is assumed that infants mostly travel with their parents, the higher risk of motor vehicle-related deaths among the infants of young mothers might be linked to drivers' inexperience or an age-related less safe driving style. ${ }^{24,25,26}$ In addition, the consequences of young drivers' crashes are more often serious than those of older drivers' crashes ${ }^{27}$ and the results of Chen et al.'s study ${ }^{28}$ suggests that in young drivers' crashes, child passengers are at an elevated risk of injuries than in older drivers' crashes. It is also known that young drivers with little driving experience are more vulnerable to distractions in terms of their capacity to control and share 
their attention and time properly between driving and in-car tasks. ${ }^{29,}{ }^{30}$ Curry et al. ${ }^{31}$ showed that it is common for young female drivers to become distracted by their passengers and to look at them while driving. This may particularly concern young mothers driving with infant passengers.

Although existing research suggests that mothers, especially if they are young with little driving experience, might be at risk as drivers, no previous studies have examined female drivers' risk of crashing when they have an infant under the age of one in the vehicle. In this study we analysed the prevalence, characteristics and risk of fatal motor vehicle crashes involving an infant passenger under the age of one by the age of the female driver in the US in 1994-2013.

\section{METHODS}

We used crash data from the Fatality Analysis Reporting System (FARS) for 1994-2013 in this study. FARS contains information regarding motor vehicle crashes on US public roads that have led to the death of at least one person within 30 days of the crash. Our analysis covered only drivers of passenger vehicles (passenger cars, minivans, utility or pickups, truck-based pickups and pickups with chamber excluded) which were not in special use (e.g. taxi or police). The selected age range for female drivers was 16-39 years, as this is the typical maternal childbirth age. In addition, this age range seems to be reasonable, as $87.8 \%$ of all female drivers with an infant passenger were in this age category. After these exclusions, the number of female drivers with an infant passenger was 3883, which was $2.7 \%$ of all female drivers aged 16-39 involved in a crash ( $n=142408)$ over the examined period, regardless of the number and age of the passengers.

\subsection{Prevalence of fatal crashes involving an infant}

The number of fatal crashes involving an infant aged under one was examined by the age of the female drivers. The number of crashes involving an infant also depended on the number of babies born in each age group. Therefore, we related the number of crashes $(n=3883)$ to the number of births ( $n=78225770)$ among each age group of mothers. As the FARS database does not include information on passengers' relations to drivers, it was assumed that female drivers travelling with an infant passenger under the age of one are mostly the mothers of these infants, and that these two measures thus approximately correspond to each other.

Information regarding births by year and age of the mother for 1994-2013 was acquired from the Birth Data Files of the National Center for Health Statistics.

We analysed the number of crashes involving an infant in relation to births for young versus older mothers/female drivers with risk ratios (RR) and their $95 \%$ confidence intervals. To check for long- 
term trends in the data, we also calculated RRs and their confidence intervals in five year periods. We defined 16-24 year-old drivers as young drivers/mothers and 25-39 year-old drivers as older drivers/mothers, because several studies have shown that drivers aged under 25 have higher crash rates than older drivers. ${ }^{32,33}$ While these age groups are not equal (16-24 year-olds consist of 9 years and 25-39 year-olds consist of 15 years), we used only ratios, rather than absolute numbers, to compare these age groups.

Finally, we also calculated the number of crashes involving an infant in relation to the number of crashes involving no passengers among young and older female drivers using RRs and their $95 \%$ confidence intervals. This was done in order to check whether the number of crashes among young and older females involving an infant differ from the number of crashes among the general population.

\subsection{Crash characteristics}

The essential characteristics of the drivers, vehicles and crashes were examined among young (16-24year-old) and older (25-39-year-old) female drivers with an infant passenger and with no passengers. In this analysis, 3883 drivers had an infant passenger and 73692 had no passengers. We explored the characteristics of crashes among different groups by percentages and compared them using the Pearson Chi square test.

\subsection{Crash risk estimation}

The ratio of at-fault drivers to not-at-fault drivers was used as the crash risk estimate for each examined driver/passenger group. We assumed that not at fault drivers involved in a crash are selected randomly and thus the number of not at fault drivers in one group represents the exposure of that group ${ }^{34}$ (for the quasi-induced exposure method, see ${ }^{35,36}$ ).

We defined drivers' probable culpability for crash occurrence (being at fault) using 'driver-related factors' (up to three or four (since 1997) coded for every driver), which are based on the police reports in the FARS database. For at fault vs. not at fault drivers' allocation, we adapted the method which was used in the Braitman et al. ${ }^{37}$ study. An involved driver was defined as being at fault if she was estimated to have fallen asleep/been fatigued, been inattentive/careless, been ill/blacked out or if she had been speeding or made traffic-related operating errors at the time of the crash. Otherwise she was not at fault (see Appendix A for a detailed definition of at fault drivers). In some crashes, the police reports considered multiple drivers (or none) culpable, so we only included crashes with one at fault driver in order to correctly define the driver's culpability. We also excluded single-vehicle crashes and those that involved persons outside the motor vehicles (e.g. pedestrians or cyclists). Finally, drivers accompanied by passengers of unknown age were excluded. 
We also assessed crash risk in the verification analysis, which covered only non-junction front-tofront crashes between two passenger vehicles in which one and only one of the drivers was marked as 'failing to keep in proper lane or running off road' or 'driving on wrong side of road'. A driver thus marked was defined as at fault driver and the other as not at fault driver. This analysis provides a more accurate definition of drivers' culpability, as both drivers involved in the crash had similar chances to divert to the opposite lane. However, the verification analysis excluded many drivers from the analysis. The number of female drivers with an infant passenger and no adult passenger was 2303 in the main analysis and 426 in the verification analysis, and the number of female drivers with no passengers was 38830 in the main analysis and 6960 in the verification analysis.

First, the effect of the female drivers' age (young vs. older) on culpability when driving with an infant was examined using binary logistic regression models. Only drivers with an infant passenger were included in this analysis. We made logistic regression models separately for the main and verification analyses, and in both models, the dependent variable was driver culpability $(1=$ at fault and $0=$ not at fault). In addition to crude odds ratios (cOR) we also calculated adjusted odds ratios (aOR). In the adjusted models the possible effect of the presence of other-aged passengers, the effect of driver drinking, driving licence validity, and the characteristics of the vehicle were controlled.

Second, we examined whether the presence of an infant in the vehicle had an effect on young and older female drivers' culpability. In order to examine the potential protective effect of an adult passenger, drivers with an infant were divided into those who also had an adult passenger (aged 16 or older) in the vehicle in addition to an infant and those who did not. The reference group in this analysis was drivers with no passengers. Separate binary logistic regression models were made for young and older females for the main and the verification analyses. Models were made separately for young and older females in order to avoid more difficult interpretations of models with interaction terms. In addition to cORs, aORs were also computed, and the effects of driver drinking, driving licence validity and vehicle characteristics on culpability were controlled.

We analysed the ratio of at-fault drivers over the whole study period of 1994-2013 in five year sections for female drivers with an infant passenger and with no passengers, and calculated the RRs and their $95 \%$ confidence intervals.

We did not examine male drivers' crash risk, as the number of male drivers with an infant and no adult passenger that met the inclusion criteria was low ( $\mathrm{N}=243$ and $\mathrm{N}=42$ in the verification analysis). In $84.1 \%$ of crashes that involved a male driver and an infant passenger, an adult passenger was also in the vehicle, whereas for female drivers this percentage was only $41.3 \%$. 


\section{RESULTS}

\subsection{Prevalence of fatal crashes involving an infant}

As shown in Figure 1, the number of fatal crashes involving an infant increased up to the female driver age of 21, after which it decreased quite linearly, in sharp contrast to the trend of all births by mother's age. This suggests that the prevalence of young female drivers with an infant passenger cannot be solely explained by the higher number of young mothers with newborns.

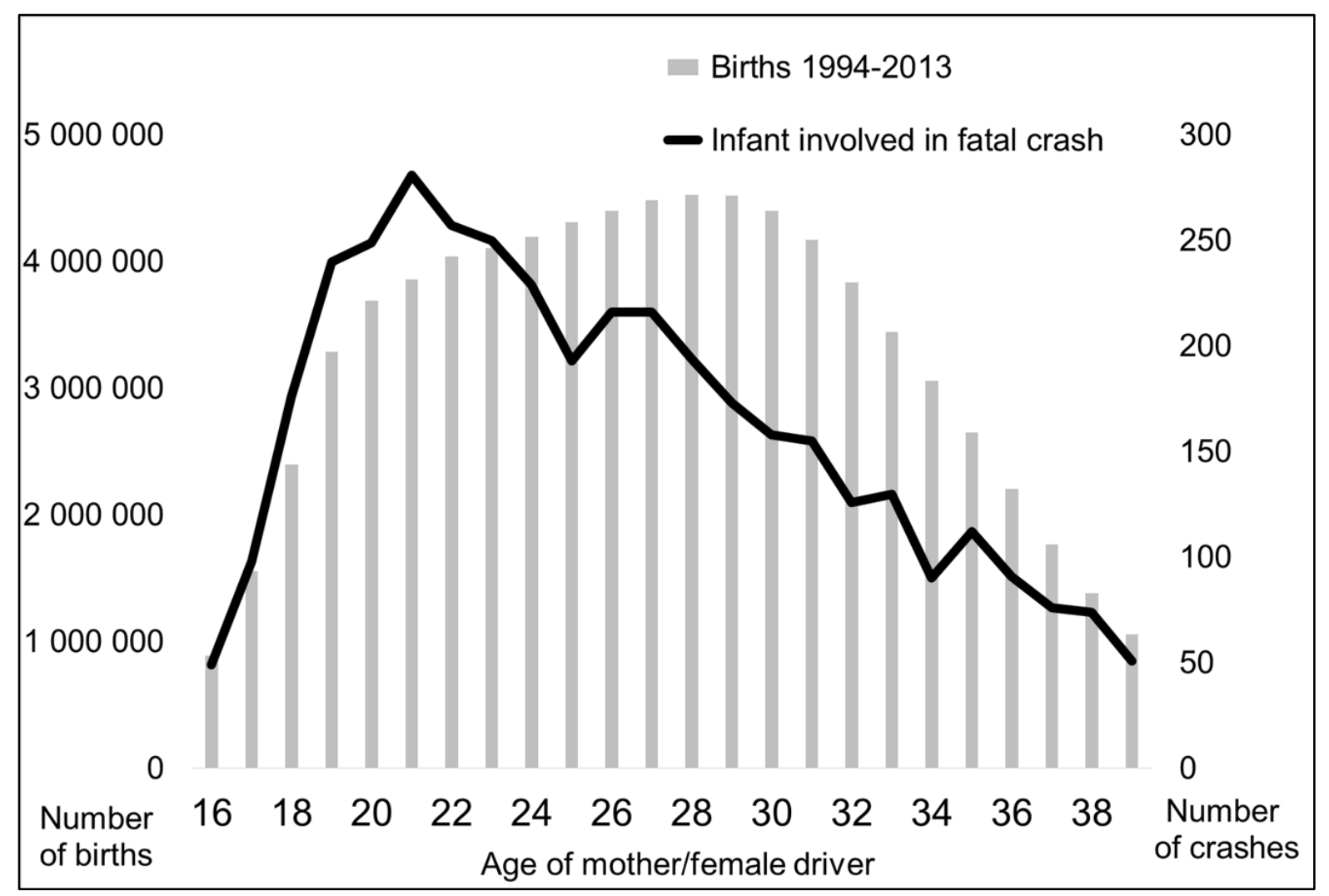

Figure 1. Number of births by age of mother and involvement of infant under the age of one in fatal crashes by age of female drivers. FARS and Birth data files 1994-2013.

The number of crashes involving an infant per 100000 births was 6.53 for 16-24-year-old females (28 013544 births and 1828 crashes) and 4.09 for 25-39-year-old females (50 212226 births and 2 055 crashes), with an RR of 1.59 (95\% CI=1.50, 1.70) for young versus older females in the whole study period of 1994-2013. This ratio has remained approximately similar and significant over time: In 1994-1998, RR=1.60 (95\% CI=1.43, 1.80); in 1999-2003, RR=1.53 (95\% CI=1.35, 1.72); in 2004-2008, RR=1.62 (95\% CI=1.42, 1.83); and in 2009-2013, RR=1.55 (95\% CI=1.34, 1.80).

For the whole study period, the number of crashes involving an infant passenger per number of crashes involving no passengers was 0.056 for 16-24-year-old female drivers (1828 crashes with an infant passenger and 32845 crashes with no passengers) and 0.050 for 25-39-year-old female drivers 
(2055 crashes with an infant passenger and 40847 crashes with no passengers), with an RR of 1.10 $(95 \% \mathrm{CI}=1.04,1.17)$.

\subsection{Crash characteristics}

Table 1 shows the characteristics of the crashes among young (16-24-year-old) and older (25-39year-old) female drivers separately for crashes involving an infant passenger and those involving no passengers.

Both young $\left(\chi^{2}(1)=28.29, \mathrm{p}<.001\right)$ and older $\left(\chi^{2}(1)=32.07, \mathrm{p}<.001\right)$ drivers with an infant were estimated to have fallen asleep or been fatigued more often than drivers with no passengers. Similarly, the percentage of drivers who were estimated to have been inattentive or careless were higher among young $\left(\chi^{2}(1)=35.12, \mathrm{p}<.001\right)$ and older $\left(\chi^{2}(1)=42.50, \mathrm{p}<.001\right)$ drivers with an infant than among drivers with no passengers.

However, the percentage of speeding or drunk drivers with no passengers was higher than that of speeding or drunk drivers with an infant passenger among both the young (speeding: $\chi^{2}(1)=19.81$, $\mathrm{p}<.001$; drunk driving: $\left.\chi^{2}(1)=147.94, \mathrm{p}<.001\right)$ and older driver (speeding: $\chi^{2}(1)=81.55, \mathrm{p}<.001$; drunk driving: $\left.\chi^{2}(1)=285.73, p<.001\right)$ age group. The drivers who were accompanied by an infant were more often involved in crashes that occurred in daylight, on a dry road surface and in rural areas than drivers with no passengers, regardless of the age of the driver. However, the percentage of drivers with a valid driving licence was higher among young $\left(\chi^{2}(1)=204.32, p<.001\right)$ and older $\left(\chi^{2}(1)\right.$ $=16.49, \mathrm{p}<.001)$ drivers with no passengers than among drivers with an infant passenger.

Young drivers more often had an infant passenger on the front seat $\left(\chi^{2}(1)=9.06, p=.003\right)$ and/or without a proper child seat $\left(\chi^{2}(1)=14.81, \mathrm{p}<.001\right)$ when the crash occurred than older drivers. In addition, in almost $39.9 \%$ of crashes, young drivers with an infant passenger were driving a vehicle that was at least 10 years old, while this was the case among older drivers with an infant in only $26.6 \%$ of crashes. It was also more typical for young drivers with an infant passenger to be involved in a crash with a passenger car than for older drivers with an infant passenger $\left(\chi^{2}(1)=148.88, p<.001\right)$ compared to other kinds of normally larger, passenger vehicles (utility, minivan or pickup). In addition, it was more common for young drivers with an infant to be speeding $\left(\chi^{2}(1)=36.18, p<.001\right)$ and/or driving without a seat belt $\left(\chi^{2}(1)=36.76, p<.001\right)$ and/or without a valid driving license $\left(\chi^{2}(1)\right.$ $=7.89, \mathrm{p}=.005)$ than for older drivers with an infant passenger. 
Table 1. Percentages of crashes when some specific factor was present in young (16-24-year-old) and older (25-39-year-old) female drivers' crashes with infant passengers and no passengers. Difference between groups tested using Pearson Chi square test.

\begin{tabular}{|c|c|c|c|c|c|c|c|}
\hline & \multicolumn{3}{|c|}{ Young drivers } & \multicolumn{3}{|c|}{ Older drivers } & \multirow[b]{2}{*}{$\begin{array}{c}\text { Chi square } \\
\text { (Young vs. } \\
\text { older drivers } \\
\text { with an } \\
\text { infant } \\
\text { passenger) } \\
\end{array}$} \\
\hline & $\begin{array}{c}\text { With an } \\
\text { infant } \\
\text { passenger } \\
(\mathrm{n}=1828) \\
\% \\
\end{array}$ & $\begin{array}{c}\text { With no } \\
\text { passenger } \\
(\mathrm{n}=32845) \\
\%\end{array}$ & $\begin{array}{c}\text { Chi } \\
\text { square } \\
\text { (with an } \\
\text { infant } \\
\text { passenger } \\
\text { vs. with } \\
\text { no } \\
\text { passenger) } \\
\end{array}$ & $\begin{array}{c}\text { With an } \\
\text { infant } \\
\text { passenger } \\
(\mathrm{n}=2055) \\
\% \\
\end{array}$ & $\begin{array}{c}\text { With no } \\
\text { passenger } \\
(\mathrm{n}=40847) \\
\%\end{array}$ & $\begin{array}{c}\text { Chi } \\
\text { square } \\
\text { (with an } \\
\text { infant } \\
\text { passenger } \\
\text { vs. with } \\
\text { no } \\
\text { passenger) } \\
\end{array}$ & \\
\hline \multicolumn{8}{|l|}{ Characteristics of driver } \\
\hline $\begin{array}{l}\text { Driver had fallen asleep or was } \\
\text { fatigued }\end{array}$ & 3.9 & 2.0 & $28.29^{* * *}$ & 3.1 & 1.5 & $32.07^{* * *}$ & $1.71^{\mathrm{ns}}$ \\
\hline Driver was inattentive or careless & 10.9 & 7.2 & $35.12^{* * * *}$ & 9.2 & 5.7 & $\mathbf{4 2 . 5 0}^{* * *}$ & $3.07^{\mathrm{ns}}$ \\
\hline Driver was speeding ${ }^{\mathrm{a}}$ & 16.2 & 20.6 & $19.81^{* * * *}$ & 9.8 & 17.5 & $81.55^{* * *}$ & $36.18^{* * *}$ \\
\hline Driver used seat belt ${ }^{\mathrm{b}}$ & 68.7 & 68.9 & $.02^{\mathrm{ns}}$ & 77.6 & 67.9 & $\mathbf{8 0 . 7 8}^{* * *}$ & $36.76^{\text {**** }}$ \\
\hline Driver had a valid driving licence ${ }^{c}$ & 84.3 & 93.3 & $204.32^{* * *}$ & 87.5 & 90.2 & $16.49^{* * *}$ & $7.89^{* *}$ \\
\hline Driver was drunk $^{\mathrm{d}}$ & 4.4 & 14.6 & $147.94^{* * *}$ & 5.5 & 20.9 & $285.73^{* * *}$ & $2.53^{\mathrm{ns}}$ \\
\hline \multicolumn{8}{|l|}{$\begin{array}{l}\text { Infant passenger-related } \\
\text { characteristic }\end{array}$} \\
\hline Infant injured fatally ${ }^{\mathrm{c}}$ & 33.4 & - & & 26.5 & - & & $21.95^{* * * *}$ \\
\hline Infant was on front seat ${ }^{\mathrm{e}}$ & 23.8 & - & & 19.8 & - & & $9.06^{* *}$ \\
\hline Infant was not in proper child seat ${ }^{\mathrm{f}}$ & 24.6 & - & & 19.3 & - & & $14.81^{* * * *}$ \\
\hline \multicolumn{8}{|l|}{ Characteristics of crash } \\
\hline Crash occurred in rural area ${ }^{c}$ & 64.1 & 55.1 & $56.08^{* * * *}$ & 57.8 & 50.3 & $43.82^{* * *}$ & $15.66^{* * *}$ \\
\hline Crash occurred at non-junction ${ }^{c}$ & 66.3 & 68.2 & $2.85^{\mathrm{ns}}$ & 62.8 & 67.8 & $22.47^{* * *}$ & $13.45^{* * *}$ \\
\hline Crash occurred in daylight ${ }^{\mathrm{c}}$ & 70.6 & 53.5 & $203.23^{* * *}$ & 72.6 & 54.1 & $269.74^{* * *}$ & $1.90^{\mathrm{ns}}$ \\
\hline $\begin{array}{l}\text { Road surface was dry when crash } \\
\text { occurred }^{c}\end{array}$ & 83.7 & 79.7 & $17.21^{* * * *}$ & 83.5 & 80.9 & $8.39^{* *}$ & $.04^{\mathrm{ns}}$ \\
\hline Crash occurred at weekend & 27.0 & 29.9 & $7.01^{* *}$ & 30.7 & 26.9 & $13.67^{* * *}$ & $6.40^{*}$ \\
\hline $\begin{array}{l}\text { Pedestrians or cyclists (or other } \\
\text { persons not in motor vehicle) } \\
\text { involved in the crash }\end{array}$ & 8.0 & 15.1 & $68.23^{* * * *}$ & 7.9 & 15.6 & $90.28^{* * *}$ & $.03^{\mathrm{ns}}$ \\
\hline Crash was single-vehicle crash ${ }^{\mathrm{g}}$ & 27.0 & 25.5 & $2.00^{\mathrm{ns}}$ & 22.3 & 23.3 & $0.96^{\mathrm{ns}}$ & $11.48^{* *}$ \\
\hline $\begin{array}{l}\text { At least one fatality occurred in } \\
\text { driver's own vehicle }\end{array}$ & 67.8 & 50.9 & $196.75^{* * *}$ & 58.1 & 47.2 & $92.54^{* * *}$ & $39.10^{* * *}$ \\
\hline \multicolumn{8}{|l|}{ Characteristics of vehicle } \\
\hline Vehicle was under 10 years old ${ }^{c}$ & 60.1 & 68.4 & $54.99^{* * * *}$ & 73.4 & 71.6 & $2.99^{\mathrm{ns}}$ & $76.94^{* * *}$ \\
\hline Vehicle was a passenger car & 71.8 & 77.5 & $32.84^{* * *}$ & 52.7 & 64.9 & $126.02^{* * *}$ & $148.88^{* * * *}$ \\
\hline
\end{tabular}

\footnotetext{
${ }^{\mathrm{ns}}$ Not significant, $* \mathrm{p}<.05, * * \mathrm{p}<.01, * * * \mathrm{p}<.001$

a We defined the driver as speeding if it was estimated that she was driving too fast for conditions, or in excess of posted speed limit, or racing.

b Percentages and Chi square tests were calculated for crashes in which information about seat belt use was known. The number of crashes for which this information was missing for 16-24-year-old drivers with an infant passenger was 97, and with no passengers 2453; and for 25-39-year-old drivers with an infant passenger 105, and with no passengers 3252 .

c Some cases were missing, but this was less than $1 \%$ of all crashes in every examined category. Percentages and Chi square tests were calculated for crashes in which information was known.

$\mathrm{d}$ We defined the driver as drunk if she had a positive BAC test value or if the police had reported alcohol involvement. As it has been indicated that alcohol is under-reported in the FARS database, especially so in BAC test results, information was probably missing in some cases of driver drinking.

e Percentages and Chi square tests were calculated for crashes in which information on infant seating position was known. This information was missing in 48 crashes in which the driver was 16-24 years old and in 77 crashes in which the driver was 25-39 years old.

f Percentages and Chi square tests were calculated for crashes in which information on infant child seat use was known. This information was missing for 91 crashes in which the driver was 16-24 years old and 91 crashes in which the driver was 25-39 years old.

g Crashes involving persons outside vehicles were excluded.
} 
For young drivers with an infant passenger it was more common that at least one fatality occurred in their own vehicle when the crash occurred than for young drivers with no passengers $\left(\chi^{2}(1)=196.75\right.$, $\mathrm{p}<.001)$ or for older drivers with an infant passenger $\left(\chi^{2}(1)=39.10, \mathrm{p}<.001\right)$. In addition, the percentage of young drivers' crashes in which an infant was fatally injured was greater than that of older drivers' crashes with an infant passenger $\left(\chi^{2}(1)=21.95, \mathrm{p}<.001\right)$. The percentage of singlevehicle crashes among young drivers with an infant passenger was also higher than that among older drivers with an infant passenger $\left(\chi^{2}(1)=11.48, \mathrm{p}<.001\right)$.

As Table 2 shows, it was more common for young drivers to be driving alone with an infant when the crash occurred than for older drivers $\left(\chi^{2}(1)=14.06, \mathrm{p}<.001\right)$. Older drivers more often had 1-4-year$\left(\chi^{2}(1)=7.33, \mathrm{p}=.007\right)$ and/or 5-15-year- $\left(\chi^{2}(1)=187.77, \mathrm{p}<.001\right)$ old child passengers and/or 40-yearold or older passengers $\left(\chi^{2}(1)=16.73, \mathrm{p}<.001\right)$ as well as an infant in the vehicle than young drivers. In addition, older drivers more often had three or more passengers in the vehicle than young drivers $\left(\chi^{2}(1)=24.54, \mathrm{p}<.001\right)$. Both young and older drivers with an infant passenger often had a passenger of the same age as themselves in addition to an infant (Table 2).

Table 2. Percentage of crashes when a passenger from some specific age category was in the vehicle as well as an infant and by number of passengers in young (16-24-year-old) and older (25-39-year-old) female drivers' crashes with infant passengers. Difference between young and older female drivers tested using Pearson Chi square test.

\begin{tabular}{lccc}
\hline & $\begin{array}{c}\text { Young drivers with } \\
\text { infant passenger } \\
\text { \% }\end{array}$ & $\begin{array}{c}\text { Older drivers with } \\
\text { infant passenger } \\
\mathbf{\%}\end{array}$ & Chi square \\
\hline Passenger configuration in addition to infant a, b & $(\mathbf{n = 1 8 1 0}$ & $(\mathbf{n = 2 0 2 5})$ & \\
Only infant(s) in the vehicle $^{c}$ & 31.8 & 26.3 & $\mathbf{1 4 . 0 6}^{* * * *}$ \\
1-4-year-old passenger(s) present & 33.9 & 38.1 & $\mathbf{7 . 3 3}^{* * *}$ \\
5-15-year-old passenger(s) present & 17.1 & 36.9 & $\mathbf{1 8 7 . 7 7}^{* * *}$ \\
16-24-year-old passenger(s) present & 31.4 & 12.0 & $\mathbf{2 1 5 . 0 3}^{* * * *}$ \\
25-39-year-old passenger(s) present & 13.5 & 21.5 & $\mathbf{4 1 . 9 9}^{* * * *}$ \\
40-year-old or older passenger(s) present & 8.5 & 12.6 & $\mathbf{1 6 . 7 3}^{* * * *}$ \\
Number of passengers & $(\mathbf{n = 1 8 2 8 )}$ & $(\mathbf{n}=\mathbf{2 0 5 5})$ & \\
One & 31.1 & 25.4 & $\mathbf{1 5 . 6 8}^{* * * *}$ \\
Two & 31.9 & 29.8 & $2.03^{\text {ns }}$ \\
Three or more & 37.0 & 44.8 & $\mathbf{2 4 . 5 4}^{* * * *}$ \\
\hline
\end{tabular}

${ }^{n s}$ Not significant, $* \mathrm{p}<.05,{ }^{*} \mathrm{p}<.01, * * * \mathrm{p}<.001$

a Please note that passengers' categories overlap, as passengers from different age categories might be in the vehicle at the same time.

' Only crashes in which information on all passengers' ages were known.

${ }^{\mathrm{c}}$ Seven 16-24 year and eleven 24-39 year old female drivers were driving with two infants. All other included drivers were driving with one infant. 


\subsection{Crash risk estimation}

First, we included only drivers with an infant passenger in the analysis in order to examine the effect of the female driver's age on the likelihood of being at fault when driving with an infant passenger (Table 3).

Young drivers with an infant passenger were more often at fault than older drivers in both the main analysis and the verification analysis (Table 3). The presence of 1-4- or 5-15-year-old children in addition to an infant had no significant effect on the likelihood of being at fault, but the presence of older passengers lowered the drivers' odds of being at fault (the presence of 16-24-year-old passengers had a marginal effect in the main analysis $\mathrm{p}=.056$ ).

Table 3. Logistic regression models using the age of the driver with (adjusted model) and without other variables (crude model) to predict driver culpability ( $1=$ at fault, $0=$ not at fault) for female drivers with an infant passenger aged under one. The verification analysis of crash risk covered only the two-passenger front-to-front vehicle crashes in which one driver diverted into the other's lane. FARS 1994-2013.

\begin{tabular}{|c|c|c|c|c|}
\hline \multirow[b]{2}{*}{ Predictors } & \multicolumn{2}{|c|}{ Crash risk } & \multicolumn{2}{|c|}{ Verification analysis of crash risk } \\
\hline & $\begin{array}{c}\text { cOR }(\mathbf{9 5 \%} \mathbf{C I}) \\
(\mathrm{n}=2327)\end{array}$ & $\begin{array}{c}\text { aOR }(95 \% \mathbf{C I}) \\
\quad(\mathrm{n}=2280)^{\mathrm{c}}\end{array}$ & $\begin{array}{c}\text { cOR }(95 \% \mathbf{C I}) \\
(\mathrm{n}=378)\end{array}$ & $\begin{array}{c}\text { aOR }(95 \% \mathbf{C I}) \\
(\mathrm{n}=373)^{\mathrm{c}}\end{array}$ \\
\hline Young driver (16-24 years old) ${ }^{a}$ & $1.99(1.69,2.35)^{* * * *}$ & $1.83(1.52,2.20)^{* * * *}$ & $3.09(2.02,4.73)^{* * * *}$ & $3.10(1.91,5.04)^{* * * *}$ \\
\hline 1-4-year-old passenger present & - & $1.06(0.89,1.28)$ & - & $0.96(0.59,1.57)$ \\
\hline 5-15-year-old passenger present & - & $1.02(0.83,1.25)$ & - & $0.62(0.35,1.08)$ \\
\hline 16-24-year-old passenger present & - & $0.80(0.64,1.01)^{+}$ & - & $0.36(0.19,0.69)^{* *}$ \\
\hline 25-39-year-old passenger present & - & $0.65(0.51,0.82)^{* * * *}$ & - & $0.43(0.22,0.85)^{*}$ \\
\hline 40-year-old or older passenger present & - & $0.73(0.55,0.97)^{*}$ & - & $0.25(0.09,0.67)^{* *}$ \\
\hline Driver was drunk & - & $4.02(2.28,7.07)^{* * *}$ & - & $2.88(0.92,8.97)$ \\
\hline Driver had no valid driving licence & - & $1.87(1.44,2.44)^{* * * *}$ & - & $2.65(1.28,5.51)^{* *}$ \\
\hline $\begin{array}{l}\text { Driver was driving } 10 \text {-year-old or older } \\
\text { vehicle }\end{array}$ & - & $1.18(0.97,1.42)$ & - & $1.44(0.88,2.37)$ \\
\hline Driver was driving passenger car ${ }^{\mathrm{b}}$ & - & $1.40(1.16,1.69)^{* *}$ & - & $1.43(0.87,2.34)$ \\
\hline Nagelkerke $\mathbf{R}^{2}$ & .038 & .090 & .097 & .232 \\
\hline-2 log-likelihood & 3128.98 & 2974.22 & 486.78 & 438.10 \\
\hline Model, overall percentage correct & 58.9 & 62.7 & 63.8 & 68.9 \\
\hline
\end{tabular}

${ }^{\text {a }}$ Reference group: 25-39-year-old drivers.

${ }^{\mathrm{b}}$ Reference group: passenger car; utility, minivan or pickup.

c Drivers with missing values excluded.

${ }^{+} \mathrm{P}=0.056$

${ }^{*} \mathrm{P}<0.05$.

${ }^{* *} \mathrm{P}<0.01$.

**** $\mathrm{P}<0.001$

In order to examine whether a passenger of any age group in addition to an infant had any effect, especially on either the young or older drivers' risk, we also entered all five interactions between driver age and presence of passenger groups (1-4-, 5-15-, 16-24-, 25-39- and 40-year-old or older) to the adjusted models, but none of the interactions were significant and neither of the models improved. 
An examination of the whole study period of 1994-2013 in five year sections showed that the at-fault rates for young and older female drivers with infant passengers stayed approximately the same (see Appendix B for RRs and all frequencies for at-fault and not-at-fault female drivers with an infant passenger).

In the second analysis (Table 4), we examined how the presence of an infant affects young and older female drivers' culpability compared to that of drivers with no passengers. In order to examine the potential protective effect of an adult passenger, drivers with an infant passenger but no adult passenger were compared separately to drivers who also had an adult passenger (16-year-old or older) in the vehicle in addition to an infant passenger. The reference group in the models was drivers with no passengers.

In the crude models, young drivers with an infant passenger and no adult passengers were more likely to be at fault than drivers with no passengers, but this difference was not significant in the verification analysis (Table 4). However, in the adjusted models, this difference was significant in both analyses $(\mathrm{aOR}=1.26,95 \% \mathrm{Cl}=1.06,1.50$, verification analysis' $\mathrm{aOR}=1.52,95 \% \mathrm{Cl}=1.01,2.29)$. This indicates that young drivers with an infant passenger but no adult passenger are at a higher crash risk than drivers with no passengers.

In contrast, for young drivers with an infant passenger and an adult passenger, the odds of being at fault were lower in relation to drivers with no passengers $(\mathrm{cOR}=0.7795 \% \mathrm{Cl}=0.65,0.92 \mathrm{aOR}=0.76$, $95 \% \mathrm{Cl}=0.63,0.92$, verification analysis $\mathrm{cOR}=0.40,95 \% \mathrm{Cl}=0.25,0.64, \mathrm{aOR}=0.40,95 \% \mathrm{Cl}=0.25$, 0.66). This indicates that when young drivers also had an adult passenger in the vehicle in addition to an infant passenger, their crash risk was lower than drivers with no passengers.

Older drivers with an infant passenger and no adult passengers were significantly less likely to be at fault than drivers with no passengers in the crude models in both analyses, but in both adjusted models the difference was no longer significant. However, older drivers with an infant and adult passenger were less likely to be at fault than drivers with no passengers in both models and analyses (Table 4). 
Table 4. Crude (cOR) and adjusted (aOR) logistic regression model for young and older drivers to predict driver culpability ( $1=$ at fault, $0=$ not at fault) when driver only had an infant passenger (aged under one) or an adult passenger (16-year-old or older) or no passengers. The verification analysis of crash risk included only the two-passenger non-junction front-to-front vehicle crashes in which one driver diverted into the other's lane. FARS 1994-2013.

\begin{tabular}{|c|c|c|c|c|}
\hline \multicolumn{5}{|l|}{ Young drivers (16-24-year-olds) } \\
\hline Predictors & $\begin{array}{c}\text { cOR }(\mathbf{9 5 \%} \mathbf{C I}) \\
(\mathrm{n}=18079) \\
\end{array}$ & $\begin{array}{c}\text { aOR }(95 \% \mathbf{C I}) \\
(\mathrm{n}=18003)^{\mathrm{c}}\end{array}$ & $\begin{array}{c}\text { cOR }(\mathbf{9 5 \%} \mathbf{C I}) \\
(\mathrm{n}=3201) \\
\end{array}$ & $\begin{array}{c}\text { aOR }(95 \% \text { CI }) \\
(\mathrm{n}=3189)^{\mathrm{c}} \\
\end{array}$ \\
\hline \multicolumn{5}{|l|}{ Passenger condition a } \\
\hline With an infant passenger & $1.21(1.02,1.44)^{*}$ & $1.26(1.06,1.50)^{* * *}$ & $1.32(0.88,1.99)$ & $1.52(1.01,2.29)^{*}$ \\
\hline $\begin{array}{l}\text { With an infant passenger and an adult } \\
\text { passenger }\end{array}$ & $0.77(0.65,0.92)^{* *}$ & $0.76(0.63,0.92)^{* *}$ & $0.40(0.25,0.64)^{* * *}$ & $0.40(0.25,0.66)^{* * * *}$ \\
\hline Driver was drunk & - & $5.94(5.09,6.93)^{* * *}$ & - & $5.25(3.82,7.20)^{* * *}$ \\
\hline Driver had no valid driving licence & - & $1.47(1.29,1.68)^{* * * *}$ & - & $1.29(0.92,1.81)$ \\
\hline $\begin{array}{l}\text { Driver was driving } 10 \text {-year-old or older } \\
\text { vehicle }\end{array}$ & - & $1.25(1.17,1.33)^{* * * *}$ & - & $1.16(0.99,1.36)$ \\
\hline Driver was driving passenger $\mathrm{car}^{\mathrm{b}}$ & - & $1.41(1.31,1.52)^{* * *}$ & - & $1.44(1.21,1.72)^{* * *}$ \\
\hline Nagelkerke $\mathbf{R}^{2}$ & 0.001 & 0.067 & 0.007 & 0.079 \\
\hline-2 log-likelihood & 24921.66 & 23907.24 & 4256.88 & 4067.00 \\
\hline Model, overall percentage correct & 54.3 & 56.8 & 61.8 & 62.3 \\
\hline
\end{tabular}

\section{Older drivers (25-39-year-olds)}

\begin{tabular}{|c|c|c|c|c|}
\hline \multirow[b]{2}{*}{ Predictors } & \multicolumn{2}{|c|}{ Crash risk } & \multicolumn{2}{|c|}{ Verification analysis of crash risk } \\
\hline & $\begin{array}{c}\text { cOR }(95 \% \text { CI }) \\
(n=23087)\end{array}$ & $\begin{array}{c}\text { aOR }(95 \% \text { CI }) \\
(n=22943)^{c}\end{array}$ & $\begin{array}{c}\text { COR }(95 \% \text { CI }) \\
(n=4136)\end{array}$ & $\begin{array}{c}\text { aOR }(95 \% \text { CI }) \\
(n=4117)^{c}\end{array}$ \\
\hline \multicolumn{5}{|l|}{ Passenger condition ${ }^{a}$} \\
\hline With an infant passenger & $0.85(0.74,0.98)^{*}$ & $1.06(0.92,1.24)$ & $0.54(0.38,0.78)^{* *}$ & $0.70(0.47,1.03)$ \\
\hline $\begin{array}{l}\text { With an infant passenger and an adult } \\
\text { passenger }\end{array}$ & $0.64(0.53,0.78)^{* * * *}$ & $0.75(0.61,0.92)^{\text {*** }}$ & $0.17(0.09,0.33)^{* * *}$ & $0.27(0.14,0.51)^{* * *}$ \\
\hline Driver had valid driving licence & - & $2.14(1.92,2.39)^{* * * *}$ & - & $2.00(1.56,2.56)^{* * * *}$ \\
\hline $\begin{array}{l}\text { Driver was driving 10-year-old or older } \\
\text { vehicle }\end{array}$ & - & $1.38(1.30,1.48)^{* * *}$ & - & $1.40(1.20,1.62)^{* * *}$ \\
\hline Driver was driving a passenger $\mathrm{car}^{\mathrm{b}}$ & - & $1.44(1.36,1.53)^{* * *}$ & - & $1.63(1.41,1.88)^{* * *}$ \\
\hline Nagelkerke $\mathbf{R}^{2}$ & 0.001 & 0.174 & 0.016 & 0.226 \\
\hline Model, overall percentage correct & 57.4 & 67.0 & 53.1 & 65.6 \\
\hline
\end{tabular}

${ }^{a}$ Reference group: no passengers.

${ }^{\mathrm{b}}$ Reference group: other passenger car; utility, minivan or pickup.

${ }^{\mathrm{c}}$ Drivers with missing values excluded.

${ }^{*} \mathrm{P}<0.05$.

${ }^{* *} \mathrm{P}<0.01$.

**** $\mathrm{P}<0.001$

See Appendix C and D (verification analysis of crash risk) for at fault rates for 16-39-year-old female drivers with no passengers and also with an infant passenger (separately with and without an adult) without age group separation. 


\section{DISCUSSION}

This study examined the prevalence, characteristics and risk of fatal motor vehicle crashes involving infants in the US during 1994-2013. Our results showed that the prevalence of fatal crashes involving infants was higher among young female drivers than among older female drivers in relation to births among mothers of a similar age (Fig 1). In addition, the number of crashes involving an infant in relation to crashes involving no passengers was higher among young than among older female drivers. Our results are in line with previous studies that have shown that infants of young mothers are at a higher risk of traffic-related death. ${ }^{22,23}$

According to our results, two factors affect the higher death risk among young mothers' infants in road accidents. First, among young female drivers with an infant passenger, the probability of dying in a crash is higher due to the lower use of safety restraints, the infant more often being on the front seat, and the use of older and smaller vehicles (Table 1). Second, our crash risk estimation showed that when driving with an infant passenger, young female drivers' crash risk was higher than that of older females (Table 3). Our results also indicate that young females with an infant passenger are at a higher crash risk than young female drivers with no passengers when there is no other adult in the vehicle (Table 4). This suggests that young drivers' higher risk with an infant passenger may not only be due to their inexperience or age-related unsafe driving style, ${ }^{27,25,26}$ but that it may also be affected by the presence of an infant or be related to young motherhood.

Our study focused on the mothers of small children, as previous research suggests that their crash risk might be elevated due to their higher levels of fatigue ${ }^{16,17}$ and their sensitivity to child-related distraction ${ }^{11,12}$. Accordingly, our results showed that female drivers with an infant passenger were more often assessed as being fatigued or inattentive than drivers with no passengers (Table 1). In addition, our results showed that female drivers' crash risk was lower when an adult passenger was also in the vehicle in addition to an infant (Table 3). This protective effect of an adult passenger can probably be explained by the fact that the other adult in the vehicle can assist the driver by taking care of the infant and enabling the driver to focus on driving.

Previous research has indicated that parents of small children avoid risks in traffic ${ }^{5}$ and crashes with child passengers usually occur under normal driving circumstances ${ }^{6,7}$. Our data also showed that crashes involving infants occurred mostly during daylight in good driving conditions, and that female drivers with infant passengers were rarely drunk or driving too fast compared to female drivers with no passengers.

Although young females with an infant passenger had less crashes related to speeding than young females with no passengers, they had more such crashes than older females with an infant passenger 
(Table 1). Speeding contributes to crash risk as well as to the seriousness of consequences. ${ }^{38}$ Our data cannot explain why young females have more speeding-related crashes, but it might be the consequence of an unsafe driving style related to inexperience and/or age-related immaturity.

Our results showed that female drivers with an infant less often had a valid driving licence than female drivers with no passengers. In addition, young females with an infant passenger less often had a valid licence than older females with an infant passenger. This may reflect socioeconomic status the inability to purchase or renew their licences due to lack of either money or time - rather than a willingness to take risks or the lack of a sense of responsibility to obey the rules of the road. Driving without a valid licence, as well as driving an old vehicle that probably lacks proper safety equipment, may also partly explain young drivers' higher risk of crashes with an infant passenger than that among young drivers with no passengers.

\subsection{Limitations}

We were unable to separate drivers into more detailed age groups than 16-24- and 25-39-year-olds, due a lack of data. Thus, our drivers' age groups may be heterogeneous with respect to, for example, driving experience and socioeconomic status.

In addition, as the FARS database only contains information on fatal crashes, which often include special characteristics such as driving without seat belts or speeding ${ }^{39}$, our results should only be generalized to less severe crashes with caution. Our estimation of the risk of crashes was based on the ratio of at-fault to not-at-fault drivers, which we defined by adapting the allocation used by Braitman et al. ${ }^{37}$ in their study. However, legal culpability is often defined by drivers' tasks, for example priority crossings, and this may bias exposure estimation. Therefore, we conducted a verification analysis in which we included only two-vehicle front-to-front non-junction crashes in which one driver diverted into the other's lane, indicating that this driver was at fault. This latter analysis provided a more accurate definition of drivers' culpability, as the two participants had similar opportunities to divert to the opposite lane.

The focus in our study was on mothers of small children, as previous research suggests that their risk might be elevated. As the FARS database does not include information on the passengers' relationship to the driver, we assumed that infant passengers aged under one were mostly transported by their parents, but it is possible that some female drivers with an infant passenger were, for example, relatives or child carers, rather than mothers. As far as we know, no data exists that could help evaluate how many of the female drivers with an infant passenger were actually mothers of these infants. In addition, it is difficult to evaluate how the risk would possibly change if the female driver with an infant passenger was not the mother. Some infant-related effects probably apply anyway (e.g. 
distraction). Non-mothers may possibly not be as fatigued as mothers, but on the other hand, driving mothers may be more careful and act more responsibly than non-mothers.

We did not examine male drivers' crash risks as the number of male drivers with an infant passenger and no adult passenger was low. Future research with larger data that also includes non-fatal crashes is needed in order to study male drivers' crash risks when driving with an infant passenger.

\section{CONCLUSIONS}

Our results suggest that young females, probably mothers in most cases, are at an elevated risk of fatal crashes when driving with an infant passenger, especially when no other adults are in the vehicle. This phenomenon continued over the period 1994-2013. In addition, among young female drivers with an infant passenger, the probability of dying in a crash was higher due to the lower use of safety restraints. Our analysis did not include males due to a low number of analysable cases, so it is possible that the effect may not be limited to only females.

It should be taken into consideration that in addition to the possible effects of small child passengers' presence or/and motherhood, the driver's age as such is probably not the only, or even main, causal factor behind the risk. It may be confounded by other factors such as inexperience, low socioeconomic status or education level. ${ }^{40,41}$ Further studies are needed to examine the impact of the presence of a small child and of parenthood, as well as drivers' age and socioeconomic status, on the risk of crashes and their consequences.

In order to reduce the motor vehicle-related deaths of infants as well as their parents, attention should be paid to the ways in which drivers' risks of incurring a crash with an infant passenger could be lowered. More support should be given to younger parents' means for safe mobility.

\section{Acknowledgments}

We thank Eladio Jiménez-Mejías and Otto Lappi for commenting on the manuscript, Jami Pekkanen for data preparation and Alice Lehtinen for proofreading.

Ida Maasalo was supported by a grant from the Finnish Traffic Safety Committee of Insurance Companies. 


\section{REFERENCES}

1. Peden, MM. World report on child injury prevention. World Health Organization.2008.

2. Rice TM, Anderson CL. The effectiveness of child restraint systems for children aged 3 years or younger during motor vehicle collisions: 1996 to 2005. Am J Public Health. 2009;99(2):252-257.

3. Macy ML, Freed GL. Child passenger safety practices in the U.S.: Disparities in light of updated recommendations. Am J Prev Med. 2012;43(3):272-281.

4. Zaza S, Sleet DA, Thompson RS, Sosin DM, Bolen JC. Reviews of evidence regarding interventions to increase use of child safety seats. Am J Prev Med. 2001;21(4):31-47.

5. Taubman - Ben-Ari O, Noy A. Does the transition to parenthood influence driving? Accid Anal Prev. 2011;43(3):1022-1035.

6. Chen IG, Durbin DR, Elliott MR, Kallan MJ, Winston FK. Trip characteristics of vehicle crashes involving child passengers. Inj Prev. 2005;11(4):219-224.

7. Scherz, RG. Fatal motor vehicle accidents of child passengers from birth through 4 years of age in Washington State. Pediatrics. 1981;68(4):572-575.

8. Kelley-Baker T, Romano E. Child passengers killed in reckless and alcohol-related motor vehicle crashes. J Safety Res. 2014;48:103-110.

9. Maasalo I, Lehtonen E, Pekkanen J, Summala H. Child passengers and driver culpability in fatal crashes by driver gender. Traffic Inj Prev. 2016;17(5):447-453.

10. Dingus A, Guo F, Lee S., Antin JF, Perez M, Buchanan-King M, Hankey J. Driver crash risk factors and prevalence evaluation using naturalistic driving data. Proc Natl Acad Sci.

2016;113(10):2636-2641. https://doi.org/10.1073/pnas.1513271113

11. Koppel S, Charlton J, Kopinathan C, Taranto D. Are child occupants a significant source of driving distraction? Accid Anal Prev. 2011;43(3):1236-1244.

12. Stutts J, Feaganes J, Reinfurt D, et al. Driver's exposure to distractions in their natural driving environment. Accid Anal Prev. 2005;37(6):1093-1101.

13. Zeifman DM. An ethological analysis of human infant crying: Answering Tinbergen's four questions. Dev Psychobiol. 2001;39(4):265-285.

14. Parks PL, Lenz ER, Milligan RA, Han HR. What happens when fatigue lingers for 18 months after delivery? J Obstet Gynecol Neonatal Nurs. 1999;28(1):87-93.

15. Filtness AJ, MacKenzie J, Armstrong K. (2014). Longitudinal change in sleep and daytime sleepiness in postpartum women. PloS one. 2014;9(7):e103513.

16. Livingstone K, Armstrong K, Obst PL, Smith SS. Postpartum fatigue and driving: relating experiences, thoughts and opinions 12 weeks post-birth. In The 4th International Conference on Women's Issues in Transportation. Transportation Research Board/National Academy of Sciences. 2009.

17. Malish S, Arastu F, O'Brien LM. A Preliminary Study of New Parents, Sleep Disruption, and Driving: A Population at Risk? Matern Child Health J. 2016;20(2):290-297.

18. O'hara MW, Swain AM. Rates and risk of postpartum depression - a meta-analysis. Int Rev Psychiatry. 1996;8(1):37-54.

19. McLennan JD, Kotelchuck M. Parental prevention practices for young children in the context of maternal depression. Pediatrics. 2000;105(5):1090-1095.

20. McLearn KT, Minkovitz CS, Strobino DM, Marks E, Hou W. The timing of maternal depressive symptoms and mothers' parenting practices with young children: implications for pediatric practice. Pediatrics. 2006;118(1):e174-e182. 
21. Wickens CM, Smart RG, Mann RE. The Impact of Depression on Driver Performance. Int J Ment Health Addict. 2014;12(4):524-537.

22. Scholer SJ, Hickson GB, Ray WA. Sociodemographic factors identify US infants at high risk of injury mortality. Pediatrics. 1999;103(6):1183-1188.

23. Emerick SJ, Foster LR, Campbell DT. Risk factors for traumatic infant death in Oregon, 1973 to 1982. Pediatrics. 1986;77(4):518-522.

24. Williams AF. Teenage drivers: patterns of risk. J Safety Res. 2003;34(1):5-15.

25. Deery HA. Hazard and risk perception among young novice drivers. J Safety Res. 2000; 30(4):225-236.

26. McKnight AJ, McKnight AS. Young novice drivers: careless or clueless? Accid Anal Prev. 2003;35(6):921-925.

27. Everett SA, Shults RA, Barrios LC, Sacks JJ, Lowry R, Oeltmann J. Trends and subgroup differences in transportation-related injury risk and safety behaviors among high school students, 1991-1997. J Adolesc Heal. 2001;28(3):228-234.

28. Chen IG, Elliott MR, Durbin DR, Winston FK. Teen drivers and the risk of injury to child passengers in motor vehicle crashes. Inj Prev. 2005;11(1):12-17.

29. Wikman A, Nieminen T, Summala H. Driving experience and time-sharing during in-car tasks on roads of different width. Ergonomics. 1998;41:358-372.

30. Young K, Regan M, Hammer M. Driver distraction: A review of the literature. In: Faulks IJ, Regan M, Stevenson M, et al, ed. Distracted driving. Sydney. NSW: Australian Collage of Road Safety; 2007:379-405.

31. Curry AE, Mirman JH, Kallan MJ, Winston FK, Durbin DR. Peer passengers: How do they affect teen crashes? J Adolesc Heal. 2012;50(6):588-594.

32. Ryan AG, Legge M, Rosman D. Age related changes in drivers' crash risk and crash type. Accid Anal Prev.1998:30(3):379-387.

33. Preusser DF, Ferguson SA, Williams AF. The effect of teenage passengers on the fatal crash risk of teenage drivers. Accid Anal Prev.1998:30(2):217-222.

34. Carr, BR. A Statistical Analysis of Rural Ontario Traffic Accidents Using Induced Exposure Data. Accid. Anal. Prev. 1969;1:343-357.

35. Chandraratna S, Stamatiadis N. Quasi-induced exposure method: Evaluation of not-at-fault assumption. Accid Anal Prev. 2009;41(2):308-313.

36. Stamatiadis N, Deacon JA. Quasi-induced exposure: Methodology and insight. Accid Anal Prev. 1997;29(1):37-52.

37. Braitman KA, Chaudhary NK, McCartt AT. Effect of passenger presence on older drivers' risk of fatal crash involvement. Traffic Inj Prev. 2014;15(5):451-456.

38. Aarts L, Van Schagen I. Driving speed and the risk of road crashes: A review. Accid Anal Prev. 2006;38(2):215-224.

39. Shibata A, Fukuda K. Risk factors of fatality in motor vehicle traffic accidents. Accid Anal Prev. 1997;26(3):391-397.

40. Mare RD. Socioeconomic effects on child mortality in the United States. Am J Public Health. 1982;72(6):539-547.

41. Lawlor DA, Shaw M. Too much too young? Teenage pregnancy is not a public health problem. Int. J. Epidemiol.2002;31(3):552-553. 


\section{APPENDIX A}

Definition of at-fault drivers (allocation adapted from Braitman et al. $2014{ }^{37}$ ). If one or more of these factors were coded, the driver was defined as being at fault; otherwise not at fault.

\begin{tabular}{|c|c|c|}
\hline Factor & $\begin{array}{l}\text { File involving this information } \\
\text { (year) }\end{array}$ & Data element and code \\
\hline \multirow{2}{*}{ Asleep or fatigued } & VEHICLE Data File (1994-2009) & DR_CF1, DR_CF2, DR_CF3 (DR_CF4): code 1 \\
\hline & DRIMPAIR Data File (2010-2013) & DRIMPAIR: code 2 \\
\hline \multirow{2}{*}{ Ill, Blackout } & VEHICLE Data File (1994-2009) & DR_CF1, DR_CF2, DR_CF3 (DR_CF4): code2 \\
\hline & DRIMPAIR Data File (2010-2013) & DRIMPAIR: code1 \\
\hline \multirow{2}{*}{ Inattentive/Careless } & $\begin{array}{l}\text { VEHICLE Data File (1994-2009 \& } \\
\text { 2012-2013) }\end{array}$ & DR_CF1, DR_CF2, DR_CF3 (DR_CF4): code 6 \\
\hline & MVIOLATN Data File (2010-2013) & MVIOLATN: code 4 \\
\hline \multirow{3}{*}{ Speeding } & VEHICLE Data File (1994-2008) & $\begin{array}{l}\text { DR_CF1, DR_CF2, DR_CF3 (DR_CF4): code 43- } \\
44\end{array}$ \\
\hline & VEHICLE Data File (1998-2008) & DR_CF1, DR_CF2, DR_CF3 (DR_CF4): code 46 \\
\hline & VEHICLE Data File (2009-2013) & SPEEDREL: 2009-2012 code 1; 2013 codes $2-5$ \\
\hline Aggressive driving/road rage & VEHICLE Data File (2004-2013) & DR_CF1, DR_CF2, DR_CF3 (DR_CF4): code 8 \\
\hline $\begin{array}{l}\text { Leaving vehicle unattended with engine } \\
\text { running }\end{array}$ & VEHICLE Data File (1994-2013) & DR_CF1, DR_CF2, DR_CF3 (DR_CF4): code 20 \\
\hline Towing or pushing vehicle improperly & VEHICLE Data File (1994-2013) & DR_CF1, DR_CF2, DR_CF3 (DR_CF4): code 22 \\
\hline $\begin{array}{l}\text { Failing to dim lights or have lights on } \\
\text { when required }\end{array}$ & VEHICLE Data File (1994-2013) & DR_CF1, DR_CF2, DR_CF3 (DR_CF4): code 23 \\
\hline Following improperly & VEHICLE Data File (1994-2013) & DR_CF1, DR_CF2, DR_CF3 (DR_CF4): code 26 \\
\hline Improper or erratic lane changing & VEHICLE Data File (1994-2013) & DR_CF1, DR_CF2, DR_CF3 (DR_CF4): code 27 \\
\hline $\begin{array}{l}\text { Failure to keep in proper lane or running } \\
\text { off road }\end{array}$ & VEHICLE Data File (1994-1999) & DR_CF1, DR_CF2, DR_CF3 (DR_CF4): code 28 \\
\hline Failure to keep in proper lane & VEHICLE Data File (2000-2013) & DR_CF1, DR_CF2, DR_CF3 (DR_CF4): code 28 \\
\hline Running off road & VEHICLE Data File (2000-2003) & DR_CF1, DR_CF2, DR_CF3 (DR_CF4): code 17 \\
\hline $\begin{array}{l}\text { Illegal driving on road shoulder, } \\
\text { sidewalk or median }\end{array}$ & VEHICLE Data File (1994-2013) & DR_CF1, DR_CF2, DR_CF3 (DR_CF4): code 29 \\
\hline $\begin{array}{l}\text { Making improper entry to or exit from } \\
\text { traffic way }\end{array}$ & VEHICLE Data File (1994-2013) & DR_CF1, DR_CF2, DR_CF3 (DR_CF4): code 30 \\
\hline Starting or backing improperly & VEHICLE Data File (1994-2013) & DR_CF1, DR_CF2, DR_CF3 (DR_CF4): code 31 \\
\hline $\begin{array}{l}\text { Opening closure into moving traffic or } \\
\text { while vehicle is in motion }\end{array}$ & VEHICLE Data File (1994-2013) & DR_CF1, DR_CF2, DR_CF3 (DR_CF4): code 32 \\
\hline Passing where prohibited & VEHICLE Data File (1994-2013) & DR_CF1, DR_CF2, DR_CF3 (DR_CF4): code 33 \\
\hline Passing on wrong side & VEHICLE Data File (1994-2013) & DR_CF1, DR_CF2, DR_CF3 (DR_CF4): code 34 \\
\hline $\begin{array}{l}\text { Passing with insufficient distance, or } \\
\text { inadequate visibility, or failing to yield } \\
\text { to overtaking vehicle }\end{array}$ & VEHICLE Data File (1994-2013) & DR_CF1, DR_CF2, DR_CF3 (DR_CF4): code 35 \\
\hline $\begin{array}{l}\text { Operating vehicle in an erratic, reckless, } \\
\text { or negligent manner; Operating at erratic } \\
\text { or suddenly changing speeds }\end{array}$ & VEHICLE Data File (1994-2013) & DR_CF1, DR_CF2, DR_CF3 (DR_CF4): code 36 \\
\hline $\begin{array}{l}\text { High-speed chase with police in pursuit } \\
\text { /police pursuing this driver or police } \\
\text { officer in pursuit }\end{array}$ & VEHICLE Data File (1994-2013) & DR_CF1, DR_CF2, DR_CF3 (DR_CF4): code 37 \\
\hline
\end{tabular}


Failure to yield right-of-way

VEHICLE Data File (1994-2013)

DR_CF1, DR_CF2, DR_CF3 (DR_CF4): code 38

Failure to obey actual traffic signs,

traffic control devices, or offices;

VEHICLE Data File (1994-2013)

DR_CF1, DR_CF2, DR_CF3 (DR_CF4): code 39

Failure to obey safety zone traffic laws

\begin{tabular}{lll}
\hline Passing through or around barrier & VEHICLE Data File (1994-2013) & DR_CF1, DR_CF2, DR_CF3 (DR_CF4): code 40 \\
\hline $\begin{array}{l}\text { Failure to observe warnings or } \\
\text { instructions on vehicles displaying them }\end{array}$ & VEHICLE Data File (1994-2013) & DR_CF1, DR_CF2, DR_CF3 (DR_CF4): code 41 \\
\hline Failure to signal intentions & VEHICLE Data File (1994-2013) & DR_CF1, DR_CF2, DR_CF3 (DR_CF4): code 42 \\
\hline Driving less than posted minimum & VEHICLE Data File (1994-2013) & DR_CF1, DR_CF2, DR_CF3 (DR_CF4): code 45 \\
\hline $\begin{array}{lll}\text { Making right turn from left-turn lane, } \\
\text { left turn from right-turn lane }\end{array}$ & VEHICLE Data File (1994-2013) & DR_CF1, DR_CF2, DR_CF3 (DR_CF4): code 47 \\
\hline Making other improper turn & VEHICLE Data File (1994-2013) & DR_CF1, DR_CF2, DR_CF3 (DR_CF4): code 48 \\
\hline Driving wrong way on one-way traffic & VEHICLE Data File (1994-2013) & DR_CF1, DR_CF2, DR_CF3 (DR_CF4): code 50 \\
\hline Driving on wrong side of the road & VEHICLE Data File (1994-2013) & DR_CF1, DR_CF2, DR_CF3 (DR_CF4): code 51 \\
\hline Stopped in roadway & VEHICLE Data File (1994-2013) & DR_CF1, DR_CF2, DR_CF3 (DR_CF4): code 54 \\
\hline Overcorrecting & VEHICLE Data File (1994-2013) & DR_CF1, DR_CF2, DR_CF3 (DR_CF4): code 58 \\
\hline
\end{tabular}




\section{APPENDIX B}

Number of at-fault and not-at-fault drivers with an infant passenger with or without an adult passenger, divided into five-year periods in 1994-2013. Risk ratio and 95\% CI calculated for young females' at-fault rate compared to older females' at-fault rate when driving with an infant passenger with or without an adult passenger.

\begin{tabular}{|c|c|c|c|c|c|c|c|c|}
\hline \multirow[b]{3}{*}{ Year } & \multirow[b]{3}{*}{$\begin{array}{l}\text { Presence of } \\
\text { adult } \\
\text { passenger }\end{array}$} & \multicolumn{6}{|c|}{ Age of mother/female driver (years) } & \multirow[t]{2}{*}{$\begin{array}{l}\text { Risk ratio } \\
(95 \% \text { CI })\end{array}$} \\
\hline & & & 16-24 & & & 25-39 & & \\
\hline & & $\begin{array}{c}\text { At } \\
\text { fault }\end{array}$ & $\begin{array}{l}\text { Not at } \\
\text { fault }\end{array}$ & $\begin{array}{l}\text { At- } \\
\text { fault } \\
\text { rate }\end{array}$ & $\begin{array}{c}\text { At } \\
\text { fault }\end{array}$ & $\begin{array}{c}\text { Not at } \\
\text { fault }\end{array}$ & $\begin{array}{l}\text { At- } \\
\text { fault } \\
\text { rate }\end{array}$ & \\
\hline \multirow{3}{*}{$\begin{array}{l}1994- \\
1998\end{array}$} & No adult & 102 & 64 & 61.4 & 94 & 147 & 39.0 & \\
\hline & Adult & 70 & 78 & 47.3 & 35 & 88 & 28.5 & \\
\hline & Sum & 172 & 142 & 54.8 & 129 & 235 & 35.4 & $1.55(1.30,1.83)$ \\
\hline \multirow{3}{*}{$\begin{array}{l}1999- \\
2003\end{array}$} & No adult & 97 & 78 & 55.4 & 94 & 137 & 40.7 & \\
\hline & Adult & 69 & 64 & 51.9 & 51 & 86 & 37.2 & \\
\hline & Sum & 166 & 142 & 53.9 & 145 & 223 & 39.4 & $1.37(1.16,1.61)$ \\
\hline \multirow{3}{*}{$\begin{array}{l}2004- \\
2008\end{array}$} & No adult & 83 & 59 & 58.5 & 73 & 111 & 39.7 & \\
\hline & Adult & 57 & 64 & 47.1 & 33 & 72 & 31.4 & \\
\hline & Sum & 140 & 123 & 53.2 & 106 & 183 & 36.7 & $1.45(1.20,1.75)$ \\
\hline \multirow{3}{*}{$\begin{array}{l}2009- \\
2013\end{array}$} & No adult & 50 & 30 & 62.5 & 46 & 85 & 35.1 & \\
\hline & Adult & 39 & 51 & 43.3 & 30 & 63 & 32.3 & \\
\hline & Sum & 89 & 81 & 52.4 & 76 & 148 & 33.9 & $1.54(1.22,1.95)$ \\
\hline \multirow{3}{*}{$\begin{array}{l}\text { Total } \\
1994- \\
2013\end{array}$} & No adult & 332 & 231 & 59.0 & 307 & 480 & 39.0 & \\
\hline & Adult & 235 & 257 & 47.8 & 149 & 309 & 32.5 & \\
\hline & Sum & 567 & 488 & 53.7 & 456 & 789 & 36.6 & $1.47(1.34,1.61)$ \\
\hline
\end{tabular}

Number of at-fault and not-at fault drivers in verification analysis

\begin{tabular}{|c|c|c|c|c|c|c|c|c|}
\hline \multirow{3}{*}{$\begin{array}{l}1994- \\
1998\end{array}$} & No adult & 31 & 8 & 79.5 & 18 & 24 & 42.9 & \\
\hline & Adult & 14 & 10 & 58.3 & 4 & 21 & 16.0 & \\
\hline & Sum & 45 & 18 & 71.4 & 22 & 45 & 32.8 & $2.18(1.49,3.17)$ \\
\hline \multirow{3}{*}{$\begin{array}{l}1999- \\
2003\end{array}$} & No adult & 18 & 11 & 62.1 & 13 & 30 & 30.2 & \\
\hline & Adult & 7 & 18 & 28.0 & 4 & 18 & 18.2 & \\
\hline & Sum & 25 & 29 & 46.3 & 17 & 48 & 26.2 & $1.77(1.07,2.92)$ \\
\hline \multirow{3}{*}{$\begin{array}{l}2004- \\
2008\end{array}$} & No adult & 15 & 11 & 57.7 & 11 & 17 & 39.3 & \\
\hline & Adult & 6 & 12 & 33.3 & 2 & 13 & 13.3 & \\
\hline & Sum & 21 & 23 & 47.7 & 13 & 30 & 30.2 & $1.58(0.91,2.73)$ \\
\hline \multirow{3}{*}{$\begin{array}{l}2009- \\
2013\end{array}$} & No adult & 10 & 5 & 66.7 & 5 & 8 & 38.5 & \\
\hline & Adult & 1 & 4 & 20.0 & 1 & 6 & 14.3 & \\
\hline & Sum & 11 & 9 & 55.0 & 6 & 14 & 30.0 & $1.83(0.84,3.99)$ \\
\hline \multirow{3}{*}{$\begin{array}{l}\text { Total } \\
1994- \\
2013\end{array}$} & No adult & 74 & 35 & 67.9 & 47 & 79 & 37.3 & \\
\hline & Adult & 28 & 44 & 38.9 & 11 & 58 & 15.9 & \\
\hline & Sum & 102 & 79 & 56.4 & 58 & 137 & 29.7 & $1.89(1.47,2.44)$ \\
\hline
\end{tabular}




\section{APPENDIX C}

At-fault rate and number of at-fault and not-at fault female drivers with an infant passenger either with or without an adult passenger, and also with no passengers by drivers' age.

\begin{tabular}{|c|c|c|c|c|c|c|c|c|c|}
\hline \multirow[b]{3}{*}{$\begin{array}{l}\text { Age of } \\
\text { driver }\end{array}$} & \multicolumn{9}{|c|}{ Passenger condition } \\
\hline & \multicolumn{3}{|c|}{$\begin{array}{l}\text { With an infant passenger } \\
\text { but no adult passenger }\end{array}$} & \multicolumn{3}{|c|}{$\begin{array}{l}\text { With an infant passenger } \\
\text { and an adult passenger }\end{array}$} & \multicolumn{3}{|c|}{ No passengers } \\
\hline & $\begin{array}{c}\text { At } \\
\text { fault }\end{array}$ & $\begin{array}{c}\text { Not at } \\
\text { fault }\end{array}$ & $\begin{array}{l}\text { At- } \\
\text { fault } \\
\text { rate }\end{array}$ & $\begin{array}{c}\text { At } \\
\text { fault }\end{array}$ & $\begin{array}{c}\text { Not at } \\
\text { fault }\end{array}$ & $\begin{array}{l}\text { At- } \\
\text { fault } \\
\text { rate }\end{array}$ & $\begin{array}{c}\text { At } \\
\text { fault }\end{array}$ & $\begin{array}{c}\text { Not at } \\
\text { fault }\end{array}$ & $\begin{array}{c}\text { At- } \\
\text { fault } \\
\text { rate }\end{array}$ \\
\hline 16 & 9 & 3 & 75.0 & 11 & 5 & 68.8 & 791 & 378 & 67.7 \\
\hline 17 & 28 & 9 & 75.7 & 19 & 5 & 79.2 & 1094 & 722 & 60.2 \\
\hline 18 & 33 & 10 & 76.7 & 34 & 19 & 64.2 & 1443 & 936 & 60.7 \\
\hline 19 & 29 & 26 & 52.7 & 37 & 28 & 56.9 & 1299 & 1015 & 56.1 \\
\hline 20 & 49 & 33 & 59.8 & 25 & 39 & 39.1 & 1118 & 974 & 53.4 \\
\hline 21 & 46 & 35 & 56.8 & 32 & 46 & 41.0 & 964 & 990 & 49.3 \\
\hline 22 & 47 & 34 & 58.0 & 25 & 41 & 37.9 & 937 & 967 & 49.2 \\
\hline 23 & 44 & 41 & 51.8 & 31 & 37 & 45.6 & 819 & 933 & 46.7 \\
\hline 24 & 47 & 40 & 54.0 & 21 & 37 & 36.2 & 767 & 877 & 46.7 \\
\hline 25 & 34 & 46 & 42.5 & 12 & 20 & 37.5 & 690 & 931 & 42.6 \\
\hline 26 & 35 & 43 & 44.9 & 16 & 37 & 30.2 & 738 & 902 & 45.0 \\
\hline 27 & 34 & 45 & 43.0 & 19 & 35 & 35.2 & 711 & 852 & 45.5 \\
\hline 28 & 33 & 42 & 44.0 & 8 & 35 & 18.6 & 642 & 799 & 44.6 \\
\hline 29 & 20 & 46 & 30.3 & 14 & 24 & 36.8 & 622 & 797 & 43.8 \\
\hline 30 & 28 & 35 & 44.4 & 13 & 13 & 50.0 & 624 & 796 & 43.9 \\
\hline 31 & 22 & 39 & 36.1 & 7 & 16 & 30.4 & 589 & 847 & 41.0 \\
\hline 32 & 15 & 37 & 28.8 & 6 & 24 & 20.0 & 555 & 811 & 40.6 \\
\hline 33 & 19 & 28 & 40.4 & 7 & 27 & 20.6 & 577 & 800 & 41.9 \\
\hline 34 & 14 & 25 & 35.9 & 6 & 9 & 40.0 & 594 & 836 & 41.5 \\
\hline 35 & 16 & 35 & 31.4 & 8 & 15 & 34.8 & 612 & 818 & 42.8 \\
\hline 36 & 9 & 17 & 34.6 & 9 & 18 & 33.3 & 560 & 786 & 41.6 \\
\hline 37 & 7 & 12 & 36.8 & 11 & 18 & 37.9 & 624 & 826 & 43.0 \\
\hline 38 & 13 & 20 & 39.4 & 6 & 6 & 50.0 & 640 & 815 & 44.0 \\
\hline 39 & 8 & 10 & 44.4 & 7 & 12 & 36.8 & 595 & 853 & 41.1 \\
\hline
\end{tabular}




\section{APPENDIX D}

At-fault rate and number of at-fault and not-at fault female drivers with an infant passenger either with or without an adult passenger and also with no passengers by drivers' age in verification analysis.

\begin{tabular}{|c|c|c|c|c|c|c|c|c|c|}
\hline \multirow[b]{3}{*}{$\begin{array}{l}\text { Age of } \\
\text { driver }\end{array}$} & \multicolumn{9}{|c|}{ Passenger condition } \\
\hline & \multicolumn{3}{|c|}{$\begin{array}{l}\text { With an infant passenger } \\
\text { but no adult passenger }\end{array}$} & \multicolumn{3}{|c|}{$\begin{array}{l}\text { With an infant passenger } \\
\text { and an adult passenger }\end{array}$} & \multicolumn{3}{|c|}{ No passengers } \\
\hline & $\begin{array}{c}\text { At } \\
\text { fault }\end{array}$ & $\begin{array}{l}\text { Not at } \\
\text { fault }\end{array}$ & $\begin{array}{l}\text { At- } \\
\text { fault } \\
\text { rate }\end{array}$ & $\begin{array}{c}\text { At } \\
\text { fault }\end{array}$ & $\begin{array}{l}\text { Not at } \\
\text { fault }\end{array}$ & $\begin{array}{l}\text { At- } \\
\text { fault } \\
\text { rate }\end{array}$ & $\begin{array}{c}\text { At } \\
\text { fault }\end{array}$ & $\begin{array}{c}\text { Not at } \\
\text { fault }\end{array}$ & $\begin{array}{l}\text { At- } \\
\text { fault } \\
\text { rate }\end{array}$ \\
\hline 16 & 2 & 0 & 100.0 & 1 & 0 & 100.0 & 160 & 54 & 74.8 \\
\hline 17 & 7 & 3 & 70.0 & 2 & 2 & 50.0 & 226 & 110 & 67.3 \\
\hline 18 & 8 & 2 & 80.0 & 5 & 4 & 55.6 & 296 & 166 & 64.1 \\
\hline 19 & 5 & 6 & 45.5 & 3 & 3 & 50.0 & 284 & 158 & 64.3 \\
\hline 20 & 14 & 3 & 82.4 & 2 & 4 & 33.3 & 203 & 150 & 57.5 \\
\hline 21 & 14 & 3 & 82.4 & 4 & 10 & 28.6 & 190 & 133 & 58.8 \\
\hline 22 & 5 & 4 & 55.6 & 5 & 8 & 38.5 & 214 & 134 & 61.5 \\
\hline 23 & 10 & 8 & 55.6 & 3 & 8 & 27.3 & 162 & 152 & 51.6 \\
\hline 24 & 9 & 6 & 60.0 & 3 & 5 & 37.5 & 146 & 124 & 54.1 \\
\hline 25 & 8 & 9 & 47.1 & 1 & 1 & 50.0 & 143 & 131 & 52.2 \\
\hline 26 & 7 & 9 & 43.8 & 1 & 7 & 12.5 & 157 & 127 & 55.3 \\
\hline 27 & 6 & 6 & 50.0 & 1 & 9 & 10.0 & 152 & 136 & 52.8 \\
\hline 28 & 5 & 8 & 38.5 & 0 & 6 & 0.0 & 153 & 104 & 59.5 \\
\hline 29 & 5 & 7 & 41.7 & 1 & 5 & 16.7 & 129 & 131 & 49.6 \\
\hline 30 & 5 & 4 & 55.6 & 3 & 3 & 50.0 & 126 & 118 & 51.6 \\
\hline 31 & 1 & 4 & 20.0 & 0 & 3 & 0.0 & 131 & 122 & 51.8 \\
\hline 32 & 4 & 6 & 40.0 & 0 & 2 & 0.0 & 128 & 144 & 47.1 \\
\hline 33 & 1 & 3 & 25.0 & 1 & 9 & 10.0 & 113 & 145 & 43.8 \\
\hline 34 & 1 & 3 & 25.0 & 0 & 0 & 0.0 & 150 & 141 & 51.5 \\
\hline 35 & 0 & 5 & 0.0 & 1 & 4 & 20.0 & 137 & 137 & 50.0 \\
\hline 36 & 2 & 3 & 40.0 & 0 & 2 & 0.0 & 139 & 137 & 50.4 \\
\hline 37 & 0 & 2 & 0.0 & 0 & 4 & 0.0 & 148 & 132 & 52.9 \\
\hline 38 & 3 & 7 & 30.0 & 0 & 2 & 0.0 & 149 & 146 & 50.5 \\
\hline 39 & 0 & 5 & 0.0 & 3 & 1 & 75.0 & 160 & 156 & 50.6 \\
\hline
\end{tabular}

